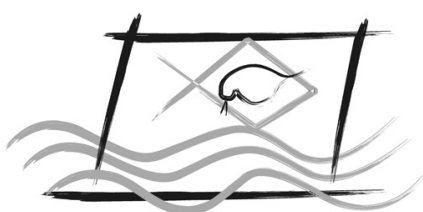

ECOTOX - BRASIL

\title{
Toxicity identification and evaluation of a refinery wastewater from Brazil (Phase I)
}

\author{
S.D.A. Daflon ${ }^{A}$; I.L. Guerra; ${ }^{A}$ M.V. Reynier ${ }^{\mathrm{B}}$; C.M.R. Botta ${ }^{\mathrm{C}}$ \& J.C. CAmpos ${ }^{\mathrm{A}}$. \\ ${ }^{a}$ Escola de Química, Universidade Federal do Rio de Janeiro. Av. Athos da Silveira Ramos, \\ 149 Sala E-206, Rio de Janeiro, Brasil.CEP:21941-909,

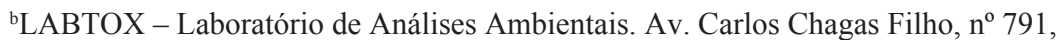 \\ Bio-Rio - Laboratório 4, - Rio de Janeiro, Brasil. CEP: 21.941-904. \\ 'Universidade de São Carlos. Av. Trabalhador Sãocarlense, 400 CP 359 São Carlos, \\ São Paulo, Brasil. CEP: 13566-590.
}

(Received March 22, 2015; Accept July 07, 2015)

\begin{abstract}
Petroleum refineries generate a large amount of effluents, which if released without appropriate treatment can cause chronic effects to organisms. Most studies show that many contaminants can be responsible for the toxicity, among them ammonia, sulfide, cyanide, phenol and hydrocarbons. The present study evaluated the cause of the chronic toxicity of a refinery wastewater from Brazil using the organism Ceriodaphnia dubia in short-term test. The results suggest that metals such as barium, manganese and strontium can be contributing for the toxicity of the wastewater. Besides this, conductivity could be contributing to the toxicity too, since the level is high for the test organism evaluated.
\end{abstract}

Keywords: C. dubia, chronic tests, refinery wastewater, toxicity identification.

\section{INTRODUCTION}

Much attention has been given to the impact of oil refinery wastewaters. This industry discharges large volumes of wastewaters containing significant amounts of toxic substances and compounds, which need to be removed at the refinery (Avci et al., 2005).

Burks (1982) stated that chemicals in oil refinery wastewaters which cause acute short-term toxicity can be removed by good biological treatment systems. However, while some refinery treatment plants can eliminate the problem of acute toxicity, the contaminant levels still remain high enough to cause chronic toxicity (Dorris et al., 1972).

Toxicity identification and evaluation (TIE) studies aim at identifying the agents responsible for wastewater toxicity, isolating the sources of this toxicity, evaluating and implementing actions to control and confirm the effectiveness of measures taken to reduce the toxic effects (USEPA, 1991).
Tischler (2013) applied TIE to refinery effluents in the USA and pointed out that the main toxicants contained in these effluents were total dissolved solids (TDS), fluoride, nitrite, ammonia, organic chemicals and metals such as copper, lead, zinc, and nickel. The author also stated that multiple waste constituents such as hardness and TDS can also reduce the bioavailability of other toxicants, e.g., metals.

Other studies suggest that compounds such as sulphides, phenol, cyanide, ammonia and hydrocarbons are responsible for refinery wastewater toxicity (Dorris et al.,1974; Hall et al., 1978; Westlake et al., 1983; Hartmann, 2004; Wake, 2005). However, few works cite metals as responsible for toxicity (Dorris et al., 1961; Pessah et al., 1973; Badaró-Pedroso, 1999; Tischler, 2013).

The composition of refinery wastewater cannot be generalized because it depends on the refinery, the type of crude oil and the units that are in operation at any specific time (Wake, 2005). Therefore, it is difficult to predict what effects

*Corresponding author: Sarah D. A. Daflon; e-mail: sarah@eq.ufrj.br 
the wastewater may have on the environment, especially on local species.

Brazil's National Environmental Council (CONAMA) issued Resolution 430, (BRASIL, 2011) covering the conditions and standards for wastewater discharge. This resolution requires industries to perform toxicity tests of their wastewater using at least two trophic levels. Besides this, the environmental agency of each state sets the permitted levels for these toxicity tests. Some environmental agencies require the refinery wastewater to have no chronic toxicity (PETROBRAS, 2005).

This article describes Phase I TIE studies performed with wastewater from a Brazilian refinery which showed chronic toxicity in a previous study. The refinery wastewater treatment plant consists of an API (American Petroleum Institute) oilwater separator (which separates oil from water by gravity), followed by flotation, aerated ponds and RBCs (rotating biological contactors).

\section{MATERIAL AND METHODS}

\section{Wastewater sample and chemical analysis.}

Grab sample was collected from the final stage of the treatment plant on July17, 2014. In the laboratory, after measurements of physical and chemical parameters, the sample was stored at $4^{\circ} \mathrm{C}$ (USEPA, 1992) for two weeks for further chemical analyses and TIE tests. The toxicity tests were initiated at the day after the arrival of the sample.

The physical and chemical parameters analyzed were: $\mathrm{pH}$, biological oxygen demand (BOD), chemical oxygen demand (COD), sulfate, nitrate, conductivity, hardness, chloride, total dissolved solids (TDS) and ammonia nitrogen. The metals analyzed were aluminum, barium, calcium, strontium, iron, magnesium, manganese, sodium and zinc.

All the parameters were measured according to the method described in the Standard Method for the Examination of Water and Wastewater (APHA, AWWA, WEF, 2005).

\section{Chronic TIE characterization scheme}

A preliminary toxicity test was performed to determine the IC25 of the sample. Based on these results, subsequent Phase I TIE manipulations were performed according to procedures developed by USEPA (1992). All manipulations were conducted with $100 \%, 50 \%$ and $25 \%(\mathrm{v} / \mathrm{v})$ concentrations plus control. Water used for dilution and control was natural water with hardness of $40 \mathrm{mg} \mathrm{L}^{-1}$ of $\mathrm{CaCO}_{3}$ and $\mathrm{pH}$ of 7.0 (adjusted to these parameters when necessary).

Baseline test was performed each time additional manipulation test was started to evaluate the toxic effects over time and to obtain data to compare with the TIE results.

As recommended by USEPA (1992) for short-term chronic tests, the sample was tested using 72-hour-old Ceriodaphnia dubia (Cladocera) in a 96-hour static-renewal test and the endpoint was reproduction. The tests were conducted with a 16:8-h light:dark photoperiod at $25 \pm 2{ }^{\circ} \mathrm{C}$. Test chambers were $12-\mathrm{mL}$ plastic tubes filled with $10 \mathrm{~mL}$ of test solution, into which one female was placed and five replicates was done.

The objective of phase I TIE procedures is to characterize classes of compounds causing toxicity in an aqueous sample. In Phase I toxicity characterization, sample manipulations included EDTA chelation, sodium thiosulfate $\left(\mathrm{Na}_{2} \mathrm{~S}_{2} \mathrm{O}_{3}\right)$ reduction, $\mathrm{pH}$ adjustment, $\mathrm{pH}$ adjustment/filtration, $\mathrm{pH}$ adjustment/aeration and $\mathrm{pH}$ adjustment/solid-phase extraction (SPE). Tests with $\mathrm{pH}$ adjustment were conducted at three pH levels: pHi (initial pH), $\mathrm{pH} \mathrm{3}$, and $\mathrm{pH} 10$. The samples were adjusted to $\mathrm{pH} 3$ and 10 by the addition of reagent-grade $\mathrm{HCl}$ and $\mathrm{NaOH}$, respectively. After manipulations (aeration, filtration, solid-phase extraction), the samples were readjusted to $\mathrm{pHi}$ by the addition of $\mathrm{NaOH}$ and $\mathrm{HCl}$, respectively, prior to testing. Two types of membranes were used in the filtration test, glass fiber $(1 \mu \mathrm{m})$ and cellulose acetate (metal binding). Only the glass fiber membrane filter was used for filtration/ $\mathrm{pH}$ adjustment. Both types of filter were conditioned with 25 $\mathrm{mL}$ of pure water and $50 \mathrm{~mL}$ of dilution water. The samples were filtered through a glass fiber membrane before passing through the column for extraction. The columns (1000 mg; $6 \mathrm{~mL}$; J.T. Baker) were conditioned with $25 \mathrm{~mL}$ of methanol followed by $25 \mathrm{~mL}$ of high pure water at a flow rate of 10 $\mathrm{mL} \min ^{-1}$. The fractionation method involved passing a 250 $\mathrm{mL}$ sample through a $\mathrm{C} 18 \mathrm{SPE}$ column with the post column sample being used in the chronic tests.

\section{Statistical analysis}

The 25\% inhibition concentration (IC25) was estimated for each test using a linear interpolation technique (USEPA, 1994). The level of inhibition of $25 \%$ (IC25\%) is proposed for chronic short-terms tests used in Phase I TIE studies and is generally suggested as an equivalent for the NOEC (USEPA, 1994). The computer program used was ICPIN.EXE (Version 2.0).

\section{RESULTS AND DISCUSSION}

\section{Chemical analyses of original wastewater sample}

Table 1 shows the results of physical and chemical analyses of the original sample and Table 2 shows the results of metals analyses.

The wastewater presents relatively high levels of hardness and conductivity (Table 1), since the test organisms are cultivated in soft water with hardness about $40 \mathrm{mg} \mathrm{L}^{-1}$ and conductivity about $160 \mu \mathrm{S} \mathrm{cm} \mathrm{cm}^{-1}$. According to the USEPA (1992), when conductivity exceeds $1000 \mu \mathrm{S} \mathrm{cm}^{-1}$ in tests with C. dubia, it can be suspected of causing toxicity, and according to the American Petroleum Institute (1998), conductivity above $2000 \mu \mathrm{S} \mathrm{cm}^{-1}$ is high enough to cause adverse effects on freshwater species. 
Goodfellow et al. (2000) highlighted that some wastewaters are toxic because of imbalance in the ion environment to which the test organisms are exposed. The authors also said that this salinity tolerance issue is more important for chronic toxicity testing because of growth and reproductive endpoints that are more sensitive to energy-taxing requirements of osmoregulation. Still according the same institute, specific ions important to freshwater species include $\mathrm{Ca}^{+}, \mathrm{K}^{+}, \mathrm{Mg}^{+}$, $\mathrm{Na}^{+}, \mathrm{Cl}^{-}, \mathrm{HCO}_{3}^{-}$and $\mathrm{SO}_{4}^{2-}$. and .

In the present study, total ammonia nitrogen (TAN) was present at a low level of $0.7 \mathrm{mg}$ (measured as N-NH3 $\mathrm{L}^{-1}$ ). According to USEPA (1979) when the sample has $\mathrm{pH}$ of 8.0 and $25^{\circ} \mathrm{C}$ of temperature, the percentage of un-ionized ammonia is $5.38 \%$. In this case, un-ionized ammonia of the sample was present at $0.037 \mathrm{mg} \mathrm{L}^{-1}$.

According to Johnson (1995) chronic toxicity of unionized ammonia generally seemed to decrease as hardness increased. The author reported IC25\% of $0.81 \mathrm{mg} \mathrm{L}^{-1}$ of unionized ammonia at $\mathrm{pH} 8.05$ and $168 \mathrm{mg} \mathrm{L}^{-1}$ of $\mathrm{CaCO}_{3}$

Nimmo et al. (1989) reported a LOEC for reduction in reproduction of $0.88 \mathrm{mg} \mathrm{L}^{-1}$ for C. dubia at $\mathrm{pH} 8$ in river water. Cowgill \& Milazzo (1991) reported a NOEC of $0.73 \mathrm{mg} \mathrm{L}^{-1}$ of $\mathrm{NH}_{3}$ in medium water at $\mathrm{pH} 8.3$ for the same organism.

According to the USEPA (1992), ammonia is suspected of causing toxicity if it is present at minimum level of $5 \mathrm{mg} \mathrm{L}^{-1}$ (total ammonia) and it toxicity will be confirmed at graduated $\mathrm{pH}$ test.

Table 1. Physical and chemical properties of original wastewater sample.

\begin{tabular}{lc}
\hline Parameter & Results \\
\hline $\mathrm{pH}$ & 8.0 \\
$\mathrm{BOD}$ & $8.6 \mathrm{mg} \mathrm{O}_{2} \mathrm{~L}^{-1}$ \\
$\mathrm{COD}$ & $112 \mathrm{mg} \mathrm{C} \mathrm{L}^{-1}$ \\
Sulfate & $120 \mathrm{mg} \mathrm{SO}_{4}^{-2} \mathrm{~L}^{-1}$ \\
Nitrate & $82 \mathrm{mg} \mathrm{NO}_{3}^{-}{\mathrm{ou} \mathrm{N}-\mathrm{NO}_{3}^{-} \mathrm{L}^{-1}}$ \\
Conductivity & $1970 \mu \mathrm{S} \mathrm{cm}^{-1}$ \\
Hardness & $180 \mathrm{mg} \mathrm{de} \mathrm{CaCO}_{3} \mathrm{~L}^{-1}$ \\
Chloride & $490 \mathrm{mgCl}^{-1}$ \\
Total dissolved solids (TDS) & $930 \mathrm{mg} \mathrm{L}^{-1}$ \\
Total ammonia nitrogen (TAN) & $0.7{\mathrm{mg} \mathrm{N}-\mathrm{NH}_{3} \mathrm{~L}^{-1}}$
\end{tabular}

Table 2. Metals found in the original wastewater sample.

\begin{tabular}{lc}
\hline Parameter & $\begin{array}{c}\text { Results } \\
\left(\mathrm{mg} \mathrm{L}^{-1}\right)\end{array}$ \\
\hline Aluminum & $<0.05$ \\
Barium & 0.51 \\
Calcium & 70 \\
Strontium & 2.4 \\
Iron & $<0.01$ \\
Magnesium & 9.5 \\
Manganese & 0.06 \\
Sodium & 359 \\
Zinc & $<0.01$
\end{tabular}

The levels of barium and strontium were respectively 0.51 $\mathrm{mg} \mathrm{L}^{-1}$ and $2.4 \mathrm{mg} \mathrm{L}^{-1}$ (Table 2), above the levels proposed by Buchman (2008) as causing chronic effects to freshwater organisms ( $0.0039 \mathrm{mg} \mathrm{L}^{-1}$ and $1.5 \mathrm{mg} \mathrm{L}^{-1}$, respectively). Also, the concentration of manganese was $0.06 \mathrm{mg} \mathrm{L}^{-1}$, higher than the acute toxicity level reported by Stubblefield et al. (1990) for C. dubia $\left(\mathrm{LC}_{50} 48 \mathrm{~h}\right.$ of $\left.0.0288 \mathrm{mg} \mathrm{L}^{-1}\right)$.

The other metals analyses, zinc $\left(<0.01 \mathrm{mg} \mathrm{L}^{-1}\right)$, iron $(<0.01$ $\left.\mathrm{mg} \mathrm{L}^{-1}\right)$ and aluminum $\left(<0.05 \mathrm{mg} \mathrm{L}^{-1}\right)$, were under the chronic levels proposed by Buchman (2008), which are $<0.12 \mathrm{mg} \mathrm{L}^{-1}$, $1.0 \mathrm{mg} \mathrm{L}^{-1}$ and $0.087 \mathrm{mg} \mathrm{L}^{-1}$, respectively.

\section{Chronic TIE manipulations}

The inhibition concentrations of $25 \% \mathrm{t}$ of the organisms (IC25\%) for the original and for the treated samples are listed in Table 3.

The addition of $0.06 \mathrm{mg} \mathrm{L}^{-1}$ of EDTA and $0.5 \mathrm{mg} \mathrm{L}^{-1}$ of $\mathrm{Na}_{2} \mathrm{~S}_{2} \mathrm{O}_{3}$ removed the wastewater toxicity, suggesting that metals are responsible for this toxicity. Hockett \& Mount (1996) achieved substantial reduction of toxicity caused by copper, cadmium and mercury (metals not analyzed in present study) by adding EDTA and $\mathrm{Na}_{2} \mathrm{~S}_{2} \mathrm{O}_{3}$.

Table 3. Toxicity of original and manipulated wastewater samples according to the chronic TIE tests.

\begin{tabular}{|c|c|c|}
\hline Manipulations & pH & CI25(\%) \\
\hline Baseline test 1 & $\mathrm{pHi}$ & 65.82 \\
\hline \multirow{2}{*}{$\mathrm{pH}$ adjustment } & $\mathrm{pH} 3$ & 65.13 \\
\hline & $\mathrm{pH} 10$ & 70.12 \\
\hline \multirow{3}{*}{$\mathrm{pH}$ adjustment/Aeration } & $\mathrm{pH} 3$ & 63.28 \\
\hline & $\mathrm{pHi}$ & Non toxic \\
\hline & $\mathrm{pH} 10$ & Non toxic \\
\hline \multirow{3}{*}{ pH adjustment/ C18 SPE } & $\mathrm{pH} 3$ & 60.13 \\
\hline & $\mathrm{pHi}$ & 67.96 \\
\hline & pH9 & 65.50 \\
\hline \multirow{3}{*}{$\mathrm{pH}$ adjustment/Filtration glass fiber } & $\mathrm{pH} 3$ & 62.10 \\
\hline & $\mathrm{pHi}$ & 67.53 \\
\hline & $\mathrm{pH} 10$ & 93.75 \\
\hline Baseline test 2 & $\mathrm{pHi}$ & 58.82 \\
\hline EDTA addition $\left(0.06 \mathrm{mg} \mathrm{L}^{-1}\right)$ & $\mathrm{pHi}$ & Non toxic \\
\hline EDTA addition $\left(0.16 \mathrm{mg} \mathrm{L}^{-1}\right)$ & $\mathrm{pHi}$ & 73.68 \\
\hline $\mathrm{Na}_{2} \mathrm{~S}_{2} \mathrm{O}_{3}$ addition $\left(0.2 \mathrm{mg} \mathrm{L}^{-1}\right)$ & pHi & 30.26 \\
\hline $\mathrm{Na}_{2} \mathrm{~S}_{2} \mathrm{O}_{3}$ addition $\left(0.5 \mathrm{mg} \mathrm{L}^{-1}\right)$ & $\mathrm{pHi}$ & Non toxic \\
\hline \multirow{2}{*}{$\mathrm{pH}$ graduation } & $\mathrm{pH} 6$ & 61.02 \\
\hline & pH9 & 67.50 \\
\hline Filtration cellulose acetate & $\mathrm{pHi}$ & Non toxic \\
\hline
\end{tabular}


Manganese, barium and strontium, as stated earlier in this study, were found to be present in concentrations capable of causing chronic toxicity and they were also chelated by EDTA addition, although they are not chelated by addition of sodium thiosulfate.

Other manipulations that removed toxicity were $\mathrm{pH}$ adjustment/aeration at initial $\mathrm{pH}$ and $\mathrm{pH}$ adjusted to 10 . These results suggest that some metals could have been precipitated after oxidation at this $\mathrm{pH}$ value, like manganese, for example (Di Bernardo, 1993).

Filtration with the $\mathrm{pH}$ adjustment to 10 also reduced toxicity, which can also be explained by the precipitation of the metal(s). According to Van Sprang \& Janssen (2001), some metals form insoluble precipitates at high $\mathrm{pH}$ and can be easily removed by filtration.

As metals were the main suspects of the wastewater toxicity according to the previous TIE tests, filtration through a cellulose acetate filter $(0.45 \mu \mathrm{m})$ was conducted, since according Weltje et al. (2003), this filter has high affinity for metals. As shown in Table 3, the toxicity was totally removed by passing the sample through this filter. In order to recover the toxicants retained by the filter, dilution water adjusted to $\mathrm{pH} 3$ was used. After that, the $\mathrm{pH}$ was readjusted to initial $\mathrm{pH}$ and tested. The test toxicity was recovered, confirming that metals are the main toxicity agents in this wastewater.

Nitrogen ammonia was measured at low level and the $\mathrm{pH}$ graduation test did not show an increase in toxicity when the sample was adjusted to $\mathrm{pH}$ 9. Thus, ammonia did not contribute to the toxicity of the sample studied.

\section{CONCLUSIONS}

Although the physical and chemical levels were below those established by the Brazilian regulation (CONAMA Resolution 430/2011), they were not sufficient to prevent the chronic toxicity of the refinery's wastewater. The TIE tests indicated that metals such as barium, strontium and manganese are present at levels capable to cause toxicity to the organism tested, but their toxicity is only reduced by EDTA addition, suggesting that other metals such as copper and cadmium (not analyzed at present study) might be contributing to the toxicity of the sample studied. In addition, special attention should be given to the high levels of conductivity, since this can also be contributing to the toxicity of the sample.

\section{ACKNOWLEDGEMENTS}

This study was partially supported by the Brazilian National Petroleum, Natural Gas and Biofuels Agency (ANP). We also thank LABTOX laboratory for support.

\section{REFERENCES}

AMERICAN PETROLEUM INSTITUTE. 1998. The toxicity of common ions to freshwater and marine organisms. Document 0300-029. Washington, DC.
APHA, AWWA, WPCF. Standard Methods for Examination of Water and Wastewater. New York. 21th ed. 2005.

AVCI, A., KAÇMAZ, M. \& DURAK, I. 2005. Peroxidation in muscle and liver tissues from fish in a contaminated river due to a petroleum refinery industry. Ecotoxicology Environmental Safety. $\quad 60(1): 101-105 . \quad$ http://dx.doi.org/10.1016/j. ecoenv.2003.10.003

BADARÓ-PEDROSO, C. 1999. Avaliação dos efeitos e identificação da toxicidade da água de produção de petróleo sobre algumas espécies marinhas. PhD Thesis, Universidade de São Paulo, São Paulo, 243p.

BRASIL. Resolução CONAMA n ${ }^{\circ} 430$. Conselho Nacional do Meio Ambiente. Brasília, Diário Oficial da União, 16 de maio de 2011.

BUCHMAN, M. F. 2008. NOOA Screening Quick Reference Tables, NOAA OR\&R Report 08-1, Seattle WA, Office Response and Restoration Division, National Oceanic and Atmospheric Administration, $34 \mathrm{p}$.

BURKS, L. S. 1982. Review of Pollutants in Petroleum Refinery Wastewaters and Effect Upon Aquatic Organisms. Environment International, 7 :271-283. http://dx.doi.org/10.1016/01604120(82)90117-9.

COWGILL, U. M. \& MILAZZO, D. P. 1991. The response of the three-brood Ceriodaphnia test to 15 formulations and pure compounds in common use. Archives of Environmental Contamination Toxicology, 21:35-40. http://dx.doi.org/10.1007/ BF01055553.

DI BERNARDO, L. Métodos e técnicas de tratamento de água. 1993. Rio de Janeiro, ABES, $2 \mathrm{v}$.

DORRIS, T. C., COPELAND, B. J. \& PATTERSON, D. 1961. The case for holding ponds. Oil Gas Journal. pp 161-165.

DORRIS, T. C., BURKS, S. L., CURD, M. R., WALLER, G. R. \& BROEME1ING, L. D. 1972. Identification of toxic components in oil refinery wastewaters and determination of their effect upon the aquatic biota. Technical Completion Report (OWRR B-017OKLA). $113 \mathrm{p}$.

DORRIS, T. C., BURKS, S. L. \& WALLER, G. R. 1974. Effects of residual toxins in oil refinery wastewater on aquatic organisms. NTIS OK-B023, Technical completion report to U.S. Dept. of Interior, Office of Water Research, Washington, DC.

GOODFEllOW, L. W., AUSLEY, L. W., BURTON, D. T., DENTON, D. L., DORN, P. B., GROTHE, D. R., HERBER, M. A., NORBERG-KING, T. J. \& RODGERS Jr., J. H. 2000. Major ion toxicity in wastewaters: a review with permitting recommendations. Environmental Toxicology and Chemistry, 19 (1): 175-182. http://dx.doi.org/10.1002/etc.5620190121

HALL Jr, L.W., BUIKEMA Jr, A.L. \& CAIRNS Jr, J. 1978. The effects of a simulated refinery wastewater on the grass shrimp Palaemonetespugio. Archives of Environmental Contamination and Toxicology 7, 23-35. http://dx.doi.org/10.1007/BF02332035

HARTMANN, C. C. 2004. Avaliação de um efluente industrial através de ensaios ecotoxicológicos e análises físicas e químicas. MSc. Dissertation. Universidade Federal do Rio Grande do Sul. Rio Grande do Sul. 101p.

HOCKETT, J. R. \& MOUNT, D. T. 1996.Use of metal chelating agents differentiate among sources of acute aquatic toxicity. Environmental Toxicology and Chemistry, 15 (10):1687-1693. http://dx.doi.org/10.1002/etc.5620151006

JOHNSON, C. G. 1995. Effects of $\mathrm{pH}$ and hardness on acute and chronic toxicity of un-ionized ammonia to Ceriodaphnia dubia. MSc. Dissertation. University of Wisconsin. 80p.

NIMMO, D.W.R., LINK, D., PARRISH, L.P., RODRIGUEZ, G.J., WUERTHELE, W. \& DAVIES, P.H. 1989. Comparison of on-site and laboratory toxicity tests: derivation of site-specific criteria for un-ionized ammonia in a Colorado transitional stream. 
Environmental Toxicology and Chemistry, 8: 1177-1189. http:// dx.doi.org/10.1002/etc.5620081211

PESSAH, E., LOCH, J.S. \& McLEOD, J.C. 1973. Preliminary report on the acute toxicity of canadian petroleum refinery wastewaters to fish. Manitoba, Fisheries Research Board of Canada. Technical Report n. 408, 43 p.

PETROBRAS. 2005. Tratamentos Avançados de Efluentes Líquidos - PROAMB 5. Technical Report. n. 7. Redução de Toxicidade Crônica em Efluentes de Refinaria. 2 p.

USEPA (Environmental Protection Agency). 1979. Aqueous Ammonia Equilibrium - Tabulation of Percent Un-ionized Ammonia. EPA/006/3-79/091. Environmental Research Laboratory, Duluth, MN.

USEPA (Environmental Protection Agency). 1991. EPA/505/290/001. Technical Support Document for Water Quality-Based Toxic Control. $2^{\text {a }}$ ed., Washington, D.C.

USEPA (Environmental Protection Agency). 1992. EPA/600/691/005F. Toxicity Identification Evaluation: Characterization of Chronically Toxicity Wastewaters, Phase I. Duluth, MN.

USEPA (Environmental Protection Agency). 1994. EPA/600/4-91002. Short-term Methods for Estimating the Chronic Toxicity of Effluents and Receiving Waters to Freshwater Organisms. Environmental Monitoring and Support Laboratory. $3^{\mathrm{a}}$ ed., Cincinnati, $\mathrm{OH}$.

VAN SPRANG, P. A. \& JANSSEN, C. R. 2001. Toxicity Identification of metals: development of toxicity identification fingerprints. Environmental Toxicology and Chemistry, 20(11) 2604-2610. http://dx.doi.org/10.1002/etc.5620201128

WAKE, H. 2005. Oil refineries: a review of their ecological impacts on the aquatic environment. Estuarine, Coastal and Shelf Science, 62:31-140. http://dx.doi.org/10.1016/j.ecss.2004.08.013

WELTJE, L. HOLLANDER, W. D. \& WOLTERBEEK, H.T. 2003. Adsorption of metals to membrane filters in view of their speciation in nutrient solution. Environmental Toxicology and Chemistry, 22(2):265-271.http://dx.doi.org/10.1002/ etc. 5620220205

WESTLAKE, G.F.; SPRAGUE, J.B. \& ROWE, D.W. 1983. Sublethal effects of treated liquid wastewater from a petroleum refinery. V. Reproduction of Daphnia pulex and overall evaluation. Aquatic Toxicology, 4:327-339.http://dx.doi.org/ 10.1016/0166-445X(83)90026-7 